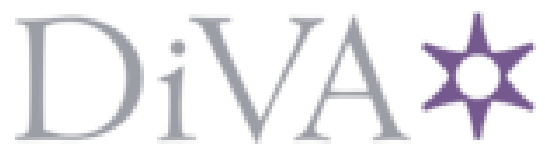

http://www.diva-portal.org

This is the published version of a chapter published in Social Movements: Transformative Shifts and Turning Points..

Citation for the original published chapter:

Olofsson, G. (2014)

From the Working-Class Movement to the New Social Movements

In: Savyasaachi \& Ravi Kumar (ed.), Social Movements: Transformative Shifts and Turning Points. (pp. 33-59). New Delhi: Routledge

N.B. When citing this work, cite the original published chapter.

Permanent link to this version:

http://urn.kb.se/resolve?urn=urn:nbn:se:lnu:diva-30682 


\section{From the Working-Class Movement to the New Social Movements'}

\section{Gunnar Olofsson}

In 1986, many social theorists regarded the 'New Social Movements' (NSMs) as possible and relevant agents of social transformation, as well as authentic representatives of post-industrial social forces. This idea of an ascending primacy of the NSMs as a subject for historical change can be found in the works of several (radical) sociologists and philosophers. Alain Touraine (1981) has given the boldest exposition of this theme, but the idea can be found in many fascinating and different varieties (Anderson 1983; Gorz 1980, 1983; Habermas 1981a, 1981b; Offe 1984; Williams 1983). In Scandinavia, similar themes have been echoed, applied and developed by sociologists (cf. CVS 1986; Friberg and Galtung 1984). This discussion takes place in the context of a shift within the intellectual left-wing discussion, especially in Denmark (E. Christensen 1985, 1986; Gundelach 1986; Thomsen 1986).

The basic argument in the NSM thesis deals with the relationship between the 'new' and the 'old' Social Movements. It implies two interconnected propositions:

(a) The historical role of the labour movement is beginning to fade away. The labour movement is too imbricated in the structures, institutions and dilemmas of the past, defending old interests and social relations, and standing in the way of a 'new project'. It is fettered by its commitment to economic growth, to the state (in its Keynesian welfare variety), and to the reality, ideals and norms of industrialism.

(b) The NSMs are the natural and self-evident successors of the labour movement. Their goals and ideas, their forms of 
struggle and organization, are perceived to be in tune with the modern age, its development trajectory and its contradictions. They hold up the promise of relevancy for the post-industrial age. The labour movement, in all its organizational and political forms - unions and parties, communism and social democracy - is perceived as that 'old' social movement that the NSMs are projected to transcend and replace.

The critical thrust in this chapter is directed against the claims of the social and theoretical centrality of the NSMs, by asking what is new and what is social in them. The major features of two old social movements will be recapitulated, focusing on the relationship between these movements and basic societal structures and processes. The implicit argument is that social movements worth their name are intrinsically related to central aspects of transformative social processes.

\section{European and American Conceptions of Social Movements}

In sociology and social history there are different concepts of 'social movement'. We can broadly distinguish between a European and an American conception. In the classical European tradition, from von Stein, Marx, Sombart and others, 'social movement' has meant organisations, focusing on major social issues, related to major social forces (or classes). In American sociology 'social movement' has been used much more empirically, meaning voluntary groups organising around a social, political or cultural issue. If they become large or popular enough they can be regarded as a 'movement' (IESS 1968). In the modern debate there is interplay between the 'European' and 'American' conceptualizations, often fruitful but sometimes confusing (Rammstedt 1978). A good example can be found in Castells' analyses of the urban social movements in the United States (US) (1977: Chapter 14). Such groups abound in European cities too, fighting against landlords and housing authorities, the town and traffic planners, demanding better schools, nursery and hospital facilities, better collective communication, less pollution and noise. 
This conceptual duality, designated here by the dichotomy 'European-American', comprises several analytical dimensions:

- Type of issue (central-marginal)

- Goal/issue-relation (comprehensive-single-issue)

- Organization (permanent representation of interest) versus campaign (momentary mobilization)

Scandinavian sociology and social history have adopted the category 'popular movement' as a common label for the whole complex of organizations born in the late 19th century. These include the trade unions and the labour movement, the temperance movement, the consumer cooperatives, the agrarian producer cooperatives, the nonconformist churches, and sometimes the sports movement (N. F. Christansen 1985; Lundkvist 1977; Olofsson 1979: Chapter 9). This concept is a regional variety of the European conceptual tradition. The popular aspect is important (cf. the next section).

\section{Classical Social Movements}

To characterize certain forms of struggle and organization as 'social movements', the European conceptual tradition presupposes a definite relationship between a social process and an organizedorganizing social collectivity. Social movements are the mediating links between basic societal processes and/or contradictions and the individual/collective reactions to these.

The social character of the social movements can be located on three separate, but tightly interconnected levels:

- Their roots in social processes and contradictions

- Their own social existence

- Their programs and goals

There is yet another decisive characteristic of social movements, namely, their popular character. Social movements are expressions of protest and programmes for change from below, that is, from social groups, strata and classes that in one way or another are repressed, marginalized, exploited, or disrespected. The social action of the nobility or the upper classes in general, or of the modern bourgeoisie, takes other political and social forms. The nascent bourgeoisie had its own distinctive forms of organization, 
epitomized in the literature on the bourgeois revolutions and in the theory of 'public sphere' (Habermas 1961). In 19th-century Denmark it was the organizational efforts of the peasants and the farmers that came to be labelled as 'social movements', not the strong and efficient, albeit much smaller and tighter organization of big landowners.

Two major and classical social movements in the European pattern have had a decisive influence on the Scandinavian societies, i.e., the farmers and peasants movement and the labour movement. Their character as social movements will be sketched in order to serve as a background, comparison and contrast to the NSMs.

\section{Agrarian Social Movements in Scandinavia - The Case of Denmark}

Starting in Denmark in the latter half of the 19th century, the organizational efforts of farmers and peasants brought about the constitution of agrarian social movements in Scandinavia. These acquired a distinctive character compared with peasant movements in Eastern and Central Europe (not to mention Asia). There the peasants' major goal was land, and the struggle was fought by a large, landless and poor agrarian proletariat. The peasant movements were organized around the land reform issues, directed against feudal social relations. The peasant parties which developed in Russia and in Eastern Europe, ranging from the Socialist Revolutionaries in Russia to the peasant parties in the Balkans and to the peasant struggle in China, became the social base for the communists. The rapid growth and the rural penetration of Finnish Social Democracy after 1900, with the poor crofters constituting the social backbone of the Reds in the Civil War 1918-19, had an 'eastern' character.

In the three Scandinavian countries the peasant movements were the outcome of a radically different situation. Their fundamental energy did not come from a land-hungry proletariat fighting their noble masters. Instead the agrarian social movements in Scandinavia, most evident in the Danish case, were part of the emergence of a rural petty bourgeoisie, of peasants and farmers in possession of their land, successfully adapting to (an increasing) dependence on the market. The change in the market relations meant both a growing entanglement in the networks of the world market, mainly the 
English, and the growing internal Danish market, due to industrialization and urbanization. This economic reorientation concurred with political modernization, with a protracted struggle for democracy.

Towards the end of the 19th century, the farmers and peasants in Denmark built up an impressive array of strong, efficient and encompassing organizations. The cooperative organizations in both production and distribution of agricultural products formed the solid nucleus in the peasant movement. They developed dairies as well as slaughterhouses; wholesale and marketing associations within the sphere of distribution, including a rurally-based consumers' co-op; credit associations for mortgages and loans as well as rural savings banks; a major political party - the liberal Venstre party - representing the interests of the farmer class; the people's high schools as an instrument for civic and cultural training; and a string of newspapers.

What made this set of often prosaic organizational activities into a social movement? They were all focused around the conditions of living and reproduction of the farmers, as individuals and families, in their neighbourhood, communities and localities. In this process the farmers were constituted into a social class. A social, political and cultural identity of a farmer class took form. The different organizations and activities complemented each other. The members, as well as the leadership and activists, cut across the whole spectrum.

At the heart of the movement were, from one perspective, those cooperatives that made the farmers' production more efficient and profitable. Modernization and the switch from cereals to animal husbandry, i.e., an adaption to the changing demand patterns in England and the intensified competition in the wheat and rye markets were combined with aggressive marketing of standardized high-quality bacon and butter. By reshaping their production, Danish farmers could survive and expand. This development was conditioned by and in turn conducive to political organization through parties. Mobilization was necessary both for the spread of cooperatives and for political organizing. In this process the cultural and ideological formation of the farmers, both as producers acting on different economic markets and as citizens in the political world of parliamentary elections and the self-government of localities, was important. Sturdy individualist producers and landowners 
were formed into a strong, cohesive and class-conscious social force. Their organizational activities were the formal side of the process of 'making a Danish farmer class'. The social situation of the individual farmer, and the farmer class as a whole, were bound together by a richly differentiated pattern of social relations and obligations, actions and organizations.

The Danish farmers' movement was a social movement in the full European sense, being a comprehensive and differentiated class project, inseparable from the constitution of the (farmer) class itself. As a class project it has been influential and effective during a long historical epoch. It has been efficient precisely because the farmers at the decisive point in time chose to fight the battle of today and tomorrow, not that of yesterday trying to recapture or resurrect a golden past. Through their successful modernization, the Danish farmers came to work along the path of development opened up by world market forces in production, distribution and consumption of food products. Their economic and cooperative organizations were at one and the same time instruments for protecting the individual farmer and the class as a whole from the vicissitudes of the market and making them able to exploit its expansionary possibilities, to surf on the crest of expansion and change. A creative reliance on the expanding export market was the driving force beneath the growth of the (then) new social movement of the farmers, an economic dilemma that made their organizational complex possible/ necessary.

\section{The Labour Movement}

The labour movement is a social movement that is specific to and characteristic of capitalist societies (for this part, cf. Olofsson 1979; Thompson 1966; Vester 1970). Labour movements exist in several different ideological and organizational configurations, richly varied in the historical trajectories of national states.

When capital through industrial expansion entered and gradually subsumed production and distribution of goods, the already existing 'lower classes' were transformed. Out of the 'people' or 'popular classes' - poor peasants, destitute artisans, and the landless poor an industrial working class gradually evolved and became a social force. These individuals and groups of workers developed a specific mode of existence, basically due to their wage-dependency. By selling 
their labour power in the market they acquired a money wage. With the money they could and had to buy goods and services in different markets, in order to reproduce themselves (and their families). The following sequence became established as their form of reproduction:

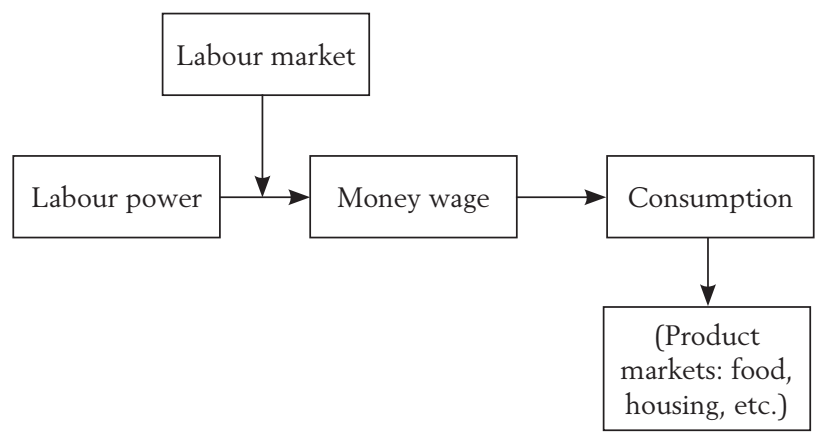

The basic forms for struggle and organization for workers have developed around the wage nexus. The transformation of a worker's potential labour power into a money wage makes at least three arenas strategic to struggle and organization: employment, wage level and working conditions. Historically, we can observe the sequence:

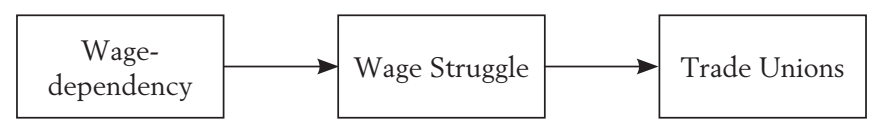

The unions try in most cases to connect the interests of workers in the labour market and on the job, i.e., in the factory/workplace.

There are also other forms of organization related to the wagedependency of the workers, to the situation where the wage is not given because of sickness, unemployment and old age. Gaps in the wage-earning capacity are potentially catastrophic for the worker (and/or his family). The resultant poverty can partly be avoided by compensatory, often insurance-based organizations (friendly societies, sickness insurance schemes). The 'solutions' to these poverty risks basically have gone the way of either self-organization (i.e., insurance-based in the form of friendly societies) or through the political agencies at state or local level (Social policy in the 
German sense). Through time, more and more of these compensatory mechanisms have been transformed into state-regulated or state-run social insurance schemes.

The transformation of money wage into means of existence food, clothing, housing, heating, and so on - is yet another structurally given focus of organization. Sharp rises in housing costs or food prices have been the preconditions for the struggle of tenants as well as housing associations, for food riots as well as consumer cooperatives.

The mediating link between these different arenas and forms of struggle and organization and the political and administrative power, lies in the political sphere, and the political parties. This characteristic aspect of modern societies is particularly important for the labour movements, whose political parties were among the first genuinely modern mass parties in many countries. In short, we find a whole family of organizations related to the emergent working class: trade unions, labour and social democratic parties (and later communist), consumer cooperatives, tenants' movements, friendly societies, and cultural organizations. What makes this set of organizations, and the practices they incorporate, into a labour movement? The different forms of struggle and organization are all various aspects of a class movement, and have been instrumental in the formation of the working class, in its 'making'. In one way or another, they all have their structural roots in the specific life form of dependent wage labour, characterized by the subjugation, exploitation and precarious living that apply to the working class under capitalist forms of production and social existence. The existential dilemmas of the wage-dependent classes - and perforce to its nucleus, the industrial working class - are the basic and structural roots and foci for the goals as well as for the strength and cohesion of the labour movements as wholes.

\section{The Labour Movement as the Decisive Social Movement in the Modern Epoch}

Why did the labour movement become the major social movement in Europe? Because it springs directly from the heart of the modern social order. Wage labour is the precondition for the accumulation of capital. Through processes of growth, change and crisis peculiar to capitalism, the working class in its formation was continually 
being challenged by processes, outcomes and changes that fostered and sometimes necessitated the kinds of struggle and organization sketched earlier in the discussion. The rise of industrial capitalism gave birth to the labour movement, and also gave it the social setting to work within.

Industrialism and its emergent new social order gave rise to a whole set of other social movements, for example, the temperance movement, the non-conformist churches, consumer cooperatives, and later the sports movement. In Scandinavia they became known as 'popular movements'. Quantitatively, these movements overshadowed the labour movement for a long time; the temperance movement was larger than the unions in Sweden (Lundkvist 1977).

Functionally, these movements can be seen as social reactions to the storms of change introduced by the transforming power of capital. The movements redirected and institutionalized reactions of despair and bewilderment in the face of the new society. They expressed the predicament of the modern capitalist society, each defining certain aspects of life as the major key to understanding, changing or accommodating the emergent social order. But, they were not as such strategically related to basic social or economic processes, in the way the labour movement was with its defining sequence:

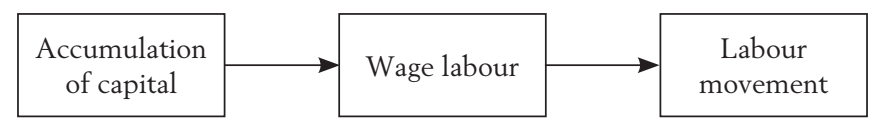

The axis between unions and the party was the defining focus for the ancillary organizations in the labour movement 'family', and the whole complex of organizations and practices was related to a class in formation, expressing a basic societal process. The labour movement has become the decisive social movement due to the role of wage labour in the basic socio-economic process - and contradiction - in modern capitalist society. It has not become the actual major social movement in every capitalist society, even though structurally it has been the possible pretender to that role.

\section{Social Movements as Class Projects}

The 'peasant movement' and the 'labour movement' became important and influential social movements because they organizationally 
and culturally transformed, in a class formative manner, reactions to decisive social changes. For the Danish farmers it was modifications in the demand for foodstuffs and changing market conditions that led to a redirection of their production - from corn to dairy and to new methods of marketing. For the labour movement it was the expansion of capital and its demand for wage labour, and the ensuing commoditisation of labour, that became the structural possibility for wage struggle and for the organization of unions.

Both movements were 'families' of interrelated and interconnected practices and organizations, to a large extent organically complementary in their nature. They were equally tied to an identifiable social force. They were class projects, both in the sense of being an expression of a distinctive class situation, and at the same time being part of the class-constituting process. These two movements had their roots in fundamental social processes and relations. The classes and 'their' movements thereby acquired a crucial position in society. As social movements they linked decisive shifts and crises in the social order with the basic interests and reproduction problems of 'their' class through a comprehensive political programme that took the form of a 'class project'. The Danish farmers and the Swedish workers (and Social Democracy) have been two typical examples.

When the NSMs are hailed as the (possible) new historical subject, then they are obviously thought of as substituting for the old movements. How do they measure up to this claim? The recapitulation mentioned earlier, which summarizes the major aspects of two old social movements, can serve as a baseline when asking for the credentials of the NSMs as social movements in the European meaning of the concept.

\section{Movement and Institution}

The difference between old and new social movements partly overlaps a famous conceptual pair in social theory, the polarity movement-institution (cf. Alberoni 1984). Movement (or bewegung, mouvement, rörelse) implies that something happens - it is where the action is. Activity, participation, engagement, and responsible and conscious action are key concepts that characterize a movement. They cover the socio-psychological and inter-organizational aspects, i.e., the relations between the participants/activists, and the struggle and goals, as well as the sociological aspects, their relation 
to society and its institutions at large. Institution here is the inversion of movement, its antidote. The dimension movement-institution can be used as a conceptual grid in analysing empirical social movements. The distinction can be more salient if other conceptual pairs, which usually coalesce in the movement-institution divide, are made explicit (see Table 2.1).

Table 2.I: Aspects of Movement-Institution

\begin{tabular}{lll}
\hline Area & Movement & Institution \\
\hline Leadership quality & Agitator & Administrator \\
Legitimacy & Charisma & Bureaucracy \\
Forms of relations & Emotional & Rational \\
Object for struggle & Radical breaks & Consolidation of gains \\
Relation to goals & Ideals & Realisation, even partial \\
Model age & Youth & Middle age \\
\hline
\end{tabular}

There are parallels between this series of oppositions and other conceptual pairs in social and political theory. Reform and revolution in the Marxist and labour tradition is one obvious case. Sartre's analysis of collectivity, with the pair series/groupe-en-fusion, is another parallel in social theory (Sartre 1976).

Any new collectivity, group or organization has, as such, more of the movement qualities than old, established organizations. Both Sartre and Alberoni have convincingly argued that 'the movement stage' cannot be perpetuated for ever. 'The nascent state' with all its accompanying emotional intensity does end (Alberoni 1984). A new movement will always have a comparative advantage with regard to the existential quality of a movement, the attraction of the not yet petrified. The movement quality of the NSMs per se is not a relevant criterion for the evaluation of new movements. It does not make them more relevant as social forces, even if they might evoke more emotional sympathy.

One crucial aspect of the dimension movement-institution deserves to be taken seriously. Real social movements take shape between the poles of 'the nascent state' and institutionalization (Alberoni 1984). The 'nascent state' of the movement, its goals, hopes and aspirations, tends to remain as a yardstick for the institution. The institution stands in relation to the movement as a realization to the programmatic ideal.

Traditional organizations have been criticized by activists and theoreticians of the NSM on two counts. First, institutions have 
been condemned for not being movements. Second, the organizational forms of 'old' movements, i.e., institutions, have been criticized for not being adequate in relation to their stated goals. When the proponents of the NSMs ask for an open and broader type of organization, not hierarchic, laying more stress on participation and responsibility, less on efficient expertise, this can either be an expression of a dream to eternalize the phase of 'the nascent state' of movements, or wanting another form of institutionalization. From the perspective of social movements as major social forces, only the latter type of critique is relevant. In the ongoing debate these two forms of assessment are typically mixed.

Movement-institution illustrates yet another distinction, between mobilization/articulation of new interests, of social forces in formation and institutionally reproduced representation of already structured and organized interests and social forces. This distinction points to the major theoretical issue in the discussion on NSMs, i.e., to the postulated confluence of social structural changes, in class structures as well as the type of dilemmas that characterize a given social formation, and the 'corresponding' social movements.

New social forces and strata have developed, and at the same time new social contradictions and predicaments have also seen the light. The emergence of the NSMs raises the question of the relation between these two sets of changes. Empirically, there is overwhelming evidence for a close relationship between the NSMs and the new social strata (the new middle-class in the public sector, especially in the welfare apparatuses) (cf. Brand 1985). Members and activists in the different NSMs are students, intellectuals and white-collar employees within social work, education, health services, and others. Since the NSMs are relatively small, we cannot turn the argument the other way and say that they are the typical organization of these strata. The argument that the NSMs are part of a process of class-formation has to rest on other than empirical arguments. As a challenge, however, it reopens a major sociological debate on the relationship between social forces and their (political) organization.

\section{The New Social Movements}

'NSMs' has become a recognized common label for a complex and widely varied set of organizations and struggles. Several of them emerged in the wake of the students' movements of the 1960s. 
They include the women's liberation movement, the peace movement, the anti-nuclear movements, the whole alternative scene (Alternativszene), urban squatters and house occupations, cooperatives and collectives, regionalist movements, the environmentalist and green organizations, and others. The wide variations among nations over time are evident in the Scandinavian as well as American, French and German literature (Brand 1983, 1985; Friberg and Galtung 1984; Paris 1981; Roth 1984; Rucht 1982; Social Research 1985; Touraine 1981).

\section{The Social Roots of the 'New Social Movements'}

The social and historical background for the NSMs is usually constructed and analysed on two different levels. The first is to look for predecessors in the 'biographical' sense, i.e., to try to find the roots of the NSM among the earlier protest and alternative movements in the 1950s and 1960s (cf. the essays in Brand [1985] for systematic trajectories of West Germany, United Kingdom, France, USA, and Sweden). These were predecessors in political style, opening up the protest and alternative sphere, with regard to both themes and models of organization. The social categories active in these early protest movements were largely the same as those populating the modern NSMs. The decisive shift from forerunners to the actual NSMs came in the wake of the students' movement of the late 1960s (ibid.).

The second approach, complementary to the first, digs deeper into the social background and relates the emergence of the NSMs to societal changes during the post-war period, especially from the 1950s onwards. The 'grand theory' of the NSMs is located on this level. The crisis of civilization, the passage from industrial to postindustrial society, with the emergence of the programmed society, reactions to the colonization of the life-world have been some of the larger contexts where the coming of the NSMs has been located (Friberg and Galtung 1984; Habermas 1981a, 1981b; Touraine 1981).

\section{The Contradiction Pre-modern-Modern}

There are two analytically different strands in this argument, both relating to the modernization of society. The post-war capitalist 
societies in Western Europe have only recently become genuinely modern societies, in the sense that capitalist social relations have marginalized pre-capitalist relations, forms of production and social classes. Durchkapitalisierung is, with the exception of the UK, a recent phenomenon. The capitalist economic process no longer exists within the framework of a social formation permeated with pre-capitalist relations, habits and institutions. The rapid reduction and the radical reshaping of the peasants and the classical urban petty bourgeoisie have led to a radical transformation of the middle-class. These archaic middle-classes were often seen as the social base of the bourgeois/capitalist forces in the political arena (cf. Schumpeter 1976).

Certain parts of the protest or alternative movements can be analysed as reactions to enforced modernization, and as reactions on the part of the pre-industrial classes or elites. Cases given are regionalist and parts of the environmentalist movements. In several European countries there has been a resurgence of regional movements, combining the interests of the cultural, political and economic peripheries in their fight for survival.

In Sweden there have been cases of resistance in the economic periphery, against the effects of not only industrialization but also against the effects of deindustrialization. Rationalization in agriculture, forestry and the traditional staple industries (steel and iron, sawmills, paper and pulp, and mining) have had serious effects on earlier major industrial areas (in the north and the mid-central Sweden). The protest (and adaption) to this situation has in some cases been channelled outside the political parties.

In Scandinavia, and especially in Sweden, another kind of reaction against enforced modernization was the much-publicized 'green wave' in the 1970s. Many young people moved out of the cities, sometimes to take up farming, often on a part-time basis, combined with reshaping everyday life (collectives), and/or artistic or political ambitions. That was part of a broader 'alternative movement', criticizing urban-industrial ways of alienated living. The commuting wage-earner existence in the newly built suburbs was contrasted with other, in a sense more traditional, images of what a good life and a decent living implied. The 'green wave' never became a mass exodus from the cities - its importance instead came to lie in the ideological resonance it evoked, as a baseline for the critique 
of the way of living, among broader social groups. Together with the mobilization around the referendum on the future of nuclear power in Sweden, held in spring 1980, it might illustrate the fusion of the protest reaction of pre- and post-industrial elites and sentiments alluded to by K. W. Brand (1983).

\section{Contradictions within Modernity}

These protests took part of their energy from the confrontation between modern and traditional life-forms. Within the most modernized parts of society a new major arena for articulation of interests developed in response to the reshaping of the conditions for reproduction of the urban wage-earning population. The protests have been 'politicized' as an effect of the growth of welfare state apparatuses and have highlighted problems such as the quality of dwellings and of urban life in general, housing rents and other costs, the organization of collective provision of day-care, public communications, parks and recreational facilities, the devastating effects of urban change and renewal through the building of highways, zoning regulations, etc. All these dilemmas and changes in the urban scene have shaped distinct possibilities for the emergence, articulation, mobilization and organization of new interests. These have been analyzed by authors on the 'new urban social movements', M. Castells (1977), among others.

In Scandinavia it is in the first place the reorganization and reshaping of the life situation for the emerging new middle-class of state employees, students, etc., that has ushered in new urban forms of protest and new political allegiances (in red and green directions). This kind of mobilization and organization, that in more than one sense is the product of the expansion of the welfare state, can be regarded as part of the NSMs.

Concurrent with this restructuration has been a radical change in the ways of living. The labour force participation rate for women increased dramatically in Scandinavia between 1960 and 1980. In Sweden this rate increased from 50 to 74 per cent, in Denmark from 43 to 71 per cent (OECD 1985). The preconditions for familial existence have as a consequence been 'socialized'. Expansion of certain welfare services, such as nurseries, school meals, institutionalized care for the elderly, and so on, is related to this development. Increasing female employment in the welfare apparatuses is 
both cause and effect, fuelling further expansion and constituting an expansionary development bloc of its own.

This radical change within the post-war capitalist societies has given birth to two analytically different sets of interests, struggles and organized activities of a movement kind. The first set focuses on the effects of the formation of individuals/subjects, roles, attitudes, and forms of social relations, especially around the constitution of gender. The second relates to interests, struggles and organization in the field of the 'socialization' of familial and individual reproduction. A growing part of the 'consumption fund', the goods and services constituting a given level-of-living, is channelled through the public sector in the form of social services. The provision of certain social services is, in the given social order, an important, growing and necessary part of the non-monetary 'social wage'. Two Danish sociologists have conceptualized the first set of movements and interests as cultural revolutionary, and the second as defence of the real social consumption (Jensen and von Nordheim Nielsen 1985).

\section{The Women's Movement: The Major Cultural Revolutionary Movement}

The immediate background for the women's liberation movement was the students' movements in the 1960s (Brand 1985). More generally, the background was the new social situation for young, educated urban women, and the changing conditions of family life. The cultural revolutionary impact of the women's movement, on values and norms for what are normal or desirable ways of living, for changes in family relations, and in the sexual division of labour in households, if not on the labour market, has been pervasive within the Scandinavian new urban middle-class. The impact has not (yet) reached the basic economic and political institutions, processes and structures.

The socialist-feminist current had wider socio-political goals. Their hopes have not yet materialized. The reason for this can be explained in two ways. One explanation points to the specific kinds of dilemma and contradictions upon which the feminist movement has worked. They are, it can be argued, of such an art that they can be complementary to a whole series of socio-political options. 
There is no relation of necessity between feminism as a cultural revolutionary option and any other definite political or ideological position. Feminism can, according to this interpretation, become articulated with forms of practices and organizations already existing. Another, much more radical conception, would argue the other way round. Feminism is the antidote to patriarchy, the latter being a fundamental principle and form of oppression so basic that it prefigures the shaping of modern, capitalist society as such.

In any case the women's movement of the 1960s had traits and characteristics that were new, compared with the old liberal and socialist women's movements. These were basically oriented towards formal-juridical and political equality (the vote, discrimination in the labour market, marriage and inheritance laws). The modern women's movement incorporated part of the programme and practice of its predecessors. (It also re-established the symbolic day of the socialist women's movement -8 March.) Politically and symbolically there has been some continuity with the old European traditions of feminist organizations, but as a social force the modern women's movement has been much more a response to the new situation of urban, especially academic women.

The main impetus came from militant American feminism, including the cultural-revolutionary aspects of consciousness-raising, a critique of received notions of femininity, which was in tune with the real changes in the lives of students and young urban middleclass women in Europe too. It was a profoundly modern movement, working along, and not against, inexorable and rapidly modernizing development processes in the restructuring of relations between family, market and the state. The self-sufficiency of the family not only as an economic unit but also as the main agent in upbringing and socialization rapidly eroded, public institutions filling the gap.

\section{'Real Consumption' Movements}

Housing facilities, traffic and planning, schools and nurseries became increasingly politicized at the same time as their role became more important. Their public character lies in the fact that they are mostly run and/or controlled by the localities, and paid through taxes. The imbrications of individual and familial existence with the sphere of welfare agencies as well as their increasing dependence upon labour and housing markets 'politicize' their social reproduction. The level- 
of-living is not decided by market forces alone. The quantity and quality of (public) services become increasingly strategic.

For the wage-earners, and for the labour movement, the ancillary organizations of consumer cooperatives, tenants' associations, building societies, etc., made the transformation of money wages into real consumption more efficient (cf. Olofsson 1979: Chapter 8). The struggle for the living standard, that is, the real wage, was on two fronts: getting a wage, and getting the most out of it. The growth of public services as a component in the real consumption makes a whole array of urban social movements a part of the struggle in the area of 'real consumption' for the modern urban wage-earners. During the last 10-15 years we have witnessed a mushrooming of new campaign groups, local, often short-lived organizations, pressure groups and even local parties fighting in the field of public provisions. In a sense they belong more to an 'American' rather than a 'European' tradition with their typical focus on single issues. Nonetheless, they can be regarded as making up a 'family' of pressure and activist groups, merging traditional middle-class pressuregroup politics with the wider concerns of emergent social strata, propelled by rapidly changing economic and social relations. It is their combination of issues and social base that gives them the form of a social movement.

\section{The New Social Movements between Class and Politics}

What relationship exists between the emergence of a new social force, the growth of a wage-dependent middle-class in public employment, and the NSMs? In this chapter, it has been argued that both the social group (public employed white-collars) and some of the most important new movements have grown out of the new contradictions in modernizing capitalist social formations, especially out of the dilemmas in the existence and reproduction for precisely the new urban wage-dependent middle-class.

Empirical investigations have shown that the social bases of the different NSMs are students, white-collars and professionals, especially those in public employment (or out of employment - cf. the German 'Alternativszene' [Brand 1985]; Gidlund 1978). This case is amply demonstrated for the Greens in Germany, but also for other Green parties (Miiller-Rommel 1985; Schmollinger 1984). On the other hand, only a small part of this new middle-class is engaged, 
as activists, sympathizers or voters, on the side of the NSMs (and parties taking up their causes).

Two hypotheses on the relation between social base and kind of politics can be formulated with regard to the NSMs in general. The first begins in the middle-class character of the voters/activists, and argues along the lines of a broadly materialist political sociology, where the right-left dimension more or less expresses the social division between bourgeois-labour, rich-poor. In this light the NSMs would be regarded as a new formation in the middle, perhaps a variety of the radical-liberal kind. (The transformation of the Italian Partito Radicale from a classical radical-liberal formation to a force giving voice to the NSMs would be an argument in reverse.) The proponents for the Green parties in Sweden, Denmark and Finland argue for the irrelevance of the right-left dimension, and could reasonably be said to be a part of a changing centre position. The Swedish Greens are represented in several local councils and seem to locate themselves in the political middle, both negatively (refusing to enter the game of 'bloc politics', with the socialist bloc confronting the bourgeois) and positively (in support of the centre or liberal parties).

This picture is far from the one the NSMs make of themselves, and those constructed by their theoreticians. It is also too crude a social reductionism. Through their background, both as movements and among their leaders and activists, they could justifiably be regarded as radical left movements, albeit transcending the traditional delimitations of left-wing politics. In the case of the German Green party, the left-wing antecedents of many of its leading spokesmen are obvious (cf. the illuminating biography of Joschka Fischer, Green minister in Hessen, in Der Spiegel 1985). In Germany the student movement in the 1960s gave birth to the revival of orthodox left-wing currents, developing into several minuscule parties and organizations in the early 1970s, carrying one or another communist/socialist label (for a fascinating account, cf. War warred der stärkste der K-partien 1977). Most of them collapsed, as have their counterparts among the groupuscules in the rest of Europe. The militants and activists from this phase of the students' movements have spread in many directions, and some have entered the NSMs. In many countries this generation of radical activists has entered the traditional parties of the left, especially if they were of an open and receptive character. Labour, socialist, 
communist, social democratic, and left socialist parties have all received their share. In some countries the threshold has been higher, due to national political traditions. In Germany the political system was more closed (Brand 1985).

The traditional interpretation of the second hypothesis is to analyse it in the terms of new alternative elites. The development of the 1960s, through the expansion of higher education and an explosion among university graduates, gave birth to new organizations of potential elites, vying for support in the population. First they tried to resurrect old political formulas from within the workingclass and communist traditions. Sometimes they had success (as in the case of the French Socialist Party) and sometimes they failed (the groupuscule strategy). When they failed, they tried new ways, among them NSMs and/or Green parties. This 'elite reductionism' is as problematic as the sociological reductionism referred to earlier. But they give elements of an explanation, with their one-sided accentuation of the structural and actor perspectives.

\section{NSMs and the New Middle Class - Keys to the Politics of the Future?}

Up until now there have been few signs that an alternative NSM or Green position as such has taken the place of the right/bourgeoisleft/socialist axis as structuring the field of European politics. The strength and saliency of the new issues and the impact of the NSMs can nonetheless be decisive in the tug-of-war between left and right political forces in the battle over the new dilemmas and issues as well as over the allegiance of the new employee middle-class. Both the issues and the new social force will play a major role in the ongoing reconstitution of political formations.

The old middle-classes of farmers and urban petty bourgeoisie, as well as the industrial working class, the traditional social bases of the right and left political formations, have rapidly diminished. The new middle-class of employees is growing. Politically they are divided along expected lines. Higher salaried employees tend to the right, lower more to the left. Other lines of division, between sexes and sectors (public-private) are also of importance (J. G. Andersen 1979; Holmberg 1981, 1984).

Strictly speaking, the new middle-class is not so much a clearly delineated and well-organized class as a set of interrelated social 
strata. What they have in common has aptly been described as a 'contradictory class location' (Wright 1978, 1985). The different parts of the 'new middle class' have different combinations of privileged/dispossessed positions with regard to qualifications, property ownership, income level, power in work organizations/hierarchies, status, etc. The appeal of the right (bourgeois, conservative and liberal forces) lies in the different forms of privilege, while the appeal of the left lies in the different forms of subordination, dispossession and powerlessness.

In Scandinavia the social democratic orthodoxy has stressed the common interests of workers and white-collars as wage-earners, by designing policies and institutions expressing and incorporating that identity. Pensions, employment policies, sick pay and expansion of education and health services have been successful policy areas. The design of the superannuation pension scheme in Sweden, Allmän tjänstepension ( white-collar workers can tice of trade unionism defines both politically and organizationally a set of common interests between workers and white-collars. The rate of unionization is exceptionally high among Swedish whitecollar workers. Unionization establishes a possible affinity that can be expressed in non-monetary union action (safety and health organizations at the workplace, co-determination schemes, and so on).

The left outside traditional social democracy can build upon traditions of working-class militancy in appealing to radicalized sections of the new middle-class, referring to the common practice of extra-parliamentary militancy. The left formulates a general apprehension of an impending crisis of capitalism, or even the industrial civilization, requiring new political formulas. In the most successful New Left political formation in Europe - the Danish Socialist People's Party - there is an obvious coexistence of old and new radical traditions, incorporating the radical wing of the labour movement (militant trade unionism) and the NSMs, especially the feminist movement. This party is now trying to merge the Red and Green strands, the radical traditions from both the old and new social movements (Christensen 1985).

The relative attraction and saliency of these alternatives for different parts of the new urban middle-classes will have a decisive impact on the political divisions in the future, because of centrality 
of the white-collar constituency. The way these new strata are interpellated from existing social forces and politico-ideological formations will mean a lot for the way the cleavages will run. The social-democratic/traditional bourgeois cleavage runs mainly along the axis of relative privilege and redistribution through public services, taxes and social security. The radical neoliberal, left-liberal and 'Green socialist' positions are pushing other issues into the foreground, and new cleavage lines may emerge, when they become articulated with existing positions, thereby transforming them (Laclau 1977; Laclau and Mouffe 1985; Fryklund and Peterson 1983).

\section{Conclusions: Making a Mountain Out of a Mole Hill?}

The NSMs have been a major and much publicized component in the political landscape of the 1970s and the early 1980s. Sociologists and social theorists try to explain these movements as the outcomes of and new answers to the present crisis of Western European societies or of modern civilization as a whole (Friberg and Galtung 1984; Touraine 1981). The dilemmas and contradictions of the modern world have been painted in broad strokes on a wide canvas. The movements that are said to be the relevant solutions to a crisis of this magnitude are, in contrast, small, unstable and even ephemeral organizations. It looks like a paradox to claim that this flickering organizational structure is the authentic answer to a deep crisis of a whole civilization.

This paradox, which is a discrepancy between an ideal historical agent, posited by a social theory, and the existing manifestation of that agent, is familiar to any student of the labour movement. In the Communist Manifesto we can find a similar discrepancy between the diagnosis of an era and the social class and movement that was designated as the privileged agent of change. It was more than 50 years from the publication of the Manifesto until the first socialist minister arrived, and even longer before social transformations in accordance with the analysis. The decisive analytical point in the Manifesto - and its further development and refinement in Marx's later works - was that it showed how the processes of capitalist growth and crisis were directly related to the struggle and organization of the working class into a labour movement, the 
social movement for which Marxism was valid. The issue was not whether the labour movement was the noblest or morally most high-standing alternative to the emergent capitalist social order there were more natural candidates for that medal among the social movements in the 19th century.

Capitalist societies reshape, as an integral part of their development, the existing poor and dependent social classes. Wherever there are capitalist social relations there is a struggle over wages, and some kind of union organization. In their fight for existence, for a better life, these classes constituted themselves into a working class and labour movement that fostered goals and organizations which could, and in many cases did, transcend the given social order. The relation between fundamental processes in capitalist social orders and a set of social movements springing directly from the heart of its contradictions and dilemmas is very intimate. It was embodied in the labour movement and resonates in the formulation of a 'scientific' as opposed to a utopian socialism.

Are the new and old social movements comparable on this account? So far this question cannot be settled. Many of the so-called new movements are remakes of older ones. The impressive peace movement activities in the early 1980s have their parallels in earlier upsurges (before 1914, in the inter-war period in the anti-nuclear movement around 1960), although the agenda has changed. The feminist movement since the 1960s continues but drastically transforms the focus of the early women's movement. In a formal sense, there is continuity between Bohemian cultures of earlier epochs and the modern pop and youth culture, but the mass character makes a decisive difference.

A point argued in this chapter is that the field of operation and the validity of the cultural revolutionary activities are politically indeterminate. They can be articulated with very different politicoideological formations, social groups and classes. As they are related to the constitution of individuals as subjects, and the micro-social relations, their transformative energy can coexist with very different macro-social trajectories. In earlier social movements there was a series of activities and organizations that could be labelled 'subcultural', forming consciousness and movements around class issues and organizations. The modern cultural revolutionary activities are more open and indeterminate, more generally counter-cultural than specifically sub-cultural. 


\section{6 ^ Gunnar Olofsson}

The defining quality of the old social movements was the close relation between the fate and existential situation of individuals and families and the major social and economic processes of an emerging, and later victorious social order. This relation was not only, or even primarily, of an ideological or normative kind, but one of socio-economic necessity. The fates of individuals, families and 'their' social class were closely linked. Along with C. W. Mills (1959) we can also say that through the social movements personal problems and social issues were connected.

Which contradiction and dilemma in modern society can give rise to a similar connection between problems and issues and to the rise of a social movement comparable to the classical? Among the existing pretenders, the most probable candidate seems to be the environmental, 'Green' movement. The relation between nature and society has become increasingly central, conflicting and complex, covering the whole field of resources, pollution, deforestation, and the nuclear issue. These questions directly relate to the personal-individual situation and behaviour and the reproductive capacity of a society and economy at large. But their effects are not specific or limited to a definite social group or even to a classin-being. Its general and non-partisan character makes the environmental question (the Green dimension) possible to articulate with different socio-political formations, not least for the socio-political centre (cf. with the earlier sectior

In some countries there has been successful 'Red-Green' constellation, evident in the Green Party in West Germany but also present in the Danish Socialist People's Party. This has been able to mobilize and constitute a loose 'family' of struggles and organization and goals, connecting the social wage-oriented urban social movements (including the alternative 'scene') with the feminist and ecological aspects, all of which are closely related to definite segments of the white-collar strata.

The threshold for constituting new and surviving social movements depends on the character of national political traditions and political systems. The more open, flexible and adaptable a political system, the less chance there is for an autonomous new major social movement to develop, and the greater the possibility of selective acceptance of new themes and issues among the already given political forces (Brand 1985). Social movements of the 'American', single-issue campaign character may be able to coalesce around the 
nexus ecology - urban social wage defence - cultural revolutionary (feminist) new middle-class base, and form a new variety of social movement in the European tradition. But it is equally probable that different parts of these new organizing potentials can become allied to already given socio-political formations, through their reshaping and interpellative capacity.

\section{Note}

1. This is a revised version of the chapter that was written for the 1985 Aalborg Conference of the Danish 'Centre for Welfare State Studies', and published in CVS (1986). In the mid-1980s I was an associate professor at the Sociological institute, University of Copenhagen and this text was written from within the Danish intellectual discussion at that time nefitted greatly from the many suggestions and comments made by 1 . Jensen, Sven E. Olsson and the editorial team of Zenit, where this version, in a Swedish translation, was published in an issue of Zenit (see Olofsson 1986: 3).

\section{References}

Alberoni, F. 1984. Movement and Institution. New York: Cambridge University Press.

Anders $\equiv$ G. 1979. Mellemlagene i Danmark. Århus: Politica.

Anders $\overline{\bar{V}}$. 1983. In the Tracks of Historical Materialism. London: Verso.

Brand, K-W. (ed.). 1985. Neue Soziale Bewegungen in Westeuropa und den USA. Ein Internationaler Vergleich. Frankfurt: Campus.

Brand, K-W, D. Biisser and D. Rucht. 1983. Aufbruch in eine Andere Gesellschafi. Frankfurt: Campus.

Castells, M. 1977. The Urban Question. London: Edward Arnold.

Christensen, E. 1985. 'Socialistisk Folkeparti - Ett danskt vänsterparti med parlamentarisk framgång', Zenit, no. 89: 55-73.

—. 1986. 'De nye sociale bevaegelser or/lösninger på velfaerdsstatens problemer', Center for Velfaer pp. 143-67.

Christiansen, N. F. 1985. 'Klassebevaegelser og folkebevaegelser'. Paper presented at the CVS seminar, May, Aalborg.

CVS. 1986. A-D. Christensen et al. (eds.) 'Velfaerdsstaten
Sociale og politiske bevaegelser', Gloder 8, Aalborg.

Der Spiegel. 1985. Dossier: Biography of Joschka Fischer, no. 45.

Die Zeit 1985. Dossier: 'Die Grünen vor der Zerreissprobe' (22-24 Mai). 
Friberg, M. and J. Galtung (eds). 1984. Rörelserna. Stockholm: Akademilitteratur.

Fryklund, B. and T. Peterson. 1983. 'Klass och folklighet', Sociologisk Forskning, no. 2: 64- 78.

Gidlund, J. 1978. Aktionsgrupper och lokala partier. Lund: CWK Gleerup.

Gorz, A. 1980. Adieux au Proletariat. Paris: Editions Galilée. . 1983. Les Chemins du Paradis. Paris: Editions Galilée.

Gundelach, P. 1986. 'Nye og gamle bevaegelser, nye og gamle teorier', CVS 1986, pp. 55-82.

Habermas, J. 1961. Strukturwandel der Öffentlichkeit. Neuwied: Luchterhand.

_. 1981 a. Theorie des kommunikativen Handelns. Frankfurt: Suhrkamp. -. 1981b. 'An Interview with Jiirgen Habermas', Telos, no. 49, pp. 5-31.

Holmberg, S. 1981. Svenska Väljare. Stockholm: Liber.

- 1984. Väljare $\equiv$ ndring. Stockholm: Liber.

International Encyclopena of the Social Sciences (IESS). 1968. 'Social Movements', International Encyclopedia of the Social Sciences, vol. 14: 438-45. New York and London: Macmillan.

Jensen, Per H. and Fritz von Nordheim Nielsen. 1985. Nye og gamle bevaegelser I relation til velfaerdsstatskomplekset, PAW Arbejdspapir, no. 8. Copenhagen: Sociological Institute.

Laclau, E. 1977. Politics and Ideology in Marxist Theory. London: NLB.

Laclau, E. and C. Mouffe. 1985. Hegemony and Socialist Strategy. London: Verso.

Lundkvist, S. 1977. Folkrörelserna $\equiv$ soenska samhället 1850-1970.
Stockholm: Sober.

Mills, C. W. 1959. The Sociological Imagination. New York: Oxford University Press.

Miiller-Rommel, F. 1985. 'The Greens in Europe', International Political Science Review, 6(4): 48-99.

Organisation for Economic Co-operation and Development (OECD). 1985. Historical Statistics 1960-1983. Paris: OECD.

Offe, C. 1984. Contradictions of the Welfare State. London: Hutchinson.

Olofsson, G. 1979. Mellan klass och stat. Lund: Arkiv.

_ 1986. "Efter arbetarrörelsen? Om vad som är "nytt" och "socialt"

Dya sociala rörelserna', Zenit, 3: 24-40

Paris, $\overline{\bar{\lambda}}$ 1981. 'Soziale Bewegung und Öffentlichkeit', Prokla, 43(2): 103-28, Berlin.

Rammstedt, O. 1978. Soziale Bewegung. Frankfurt: Suhrkamp.

Roth, R. 1984. 'Analysen af nye sociale bevaegelser - Teorier og begreber', Kurasje, no. 34: 49-68, Copenhagen.

Rucht, D., 1982. 'Neue soziale Bewegungen oder: Die Grenzen biirokratischer Modernisierun Sonderheft, 13: 272-91. 
Sartre, J. P. 1976. Critique of Dialectical Reason. London: NLB.

Schmollinger, S. 1984. 'Bundestagswahlen und soziale Basis politischer Parteien in der Bundersrepublik, Prokla, 56(September): 21-50.

Schumpeter, J. 1976. Capitalism, Socialism and Democracy. London: Allen \& Unwin.

Social Research. 1985. Winter issue on 'Social Movements', 52(4).

Thompson, E. P. 1966. The Making of the English Working Class. New York: Vintage.

Thomsen, L. 1986. 'Sociale bevaegelser og social forandring', CVS, pp. 9-32.

Touraine, A. 1981. The Voice and the Eye: An Analysis of Social Movements. Cambridge: Cambridge University Press.

Vester, M. 1970. Die Entstehung des Prolatariats als Lernprozess. Frankfurt: EVA.

Williams, R. 1983. Towards 2000. London: Chatto \& Windus.

Anon. 1977. Wir waren die stärkste der Parteien ... Erfahrungsberichte am der Welt der K-parteien. Berlin: Rotbuch Verlag.

Wright, E. O. 1985. Classes. London: Verso.

- 1978. Class, Crisis and the State. London: NLB. 